\title{
大学女子テニス選手におけるビタミン $\mathrm{B}_{1}, \mathrm{~B}_{2} ， \mathrm{C}$ 摂取量と ビタミンの栄養状態との関連性
}

関 根 豊子, 高橋 裕 子, 井上喜久子, 樋 口満 国立健康 · 栄養研究所

\author{
Vitamins $\mathrm{B}_{1}, \mathrm{~B}_{2}$ and C Status in Female Collegiate Tennis Players \\ Toyoko Sekine, Yuko Takahashi, Kikuko Inoue and Mitsuru Higuchi \\ National Institute of Health and Nutrition
}

This study evaluated the water-soluble vitamin status (vitamin $\mathrm{B}_{1}\left(\mathrm{VB}_{1}\right)$, Vitamin $\mathrm{B}_{2}\left(\mathrm{VB}_{2}\right)$ and vitamin $\mathrm{C}(\mathrm{VC})$ ) in female collegiate tennis players and untrained students. The tennis players who took some supplements had a higher level of energy intake than those without supplements and the untrained students. Although the $\mathrm{VB}_{1}$ intake by tennis players without supplements and by the untrained students was higher than the RDA level, their $V_{1} B_{1}$ status in terms of the TDP (thiamin diphosphate) effect was generally inappropriate. The tennis players without supplements showed a significant inverse correlation between the $\mathrm{VB}_{1}$ intake $(\mathrm{mg} / 1,000 \mathrm{kcal})$ and TDP effect. A regression analysis indicated that the $\mathrm{VB}_{1}$ intake corresponding to the upper level of the normal area (18\%) for TDP effect was 0.60mg. The $\mathrm{VB}_{2}$ intake by tennis players without supplements and by the untrained students was also higher than the RDA level, and an appropriate $\mathrm{VB}_{2}$ status in terms of the FAD (flavin adenine dinucleotide) effect was apparent in the tennis players and untrained students. The tennis players who took some supplements had a considerably highly intake of both $\mathrm{VB}_{1}$ and $\mathrm{VB}_{2}$ than the respective $\mathrm{RDA}$ levels, and their vitamin status was appropriate. The tennis players both with and without supplements had a markedly higher VC intake than the RDA level, while the untrained students had a slightly lower level of VC intake than the RDA level. All subjects had appropriate level of serum VC concentration.

Jpn. J. Nutr., 59 (2) $79 \sim 86$ (2001)

目的

スポーツ選手にとって適切なエネルギー及び各栄養素 の摂取は, 健康管理と競技力向上に不可欠である。日々 トレーニングや試合を行っているスポーツ選手は, 身体 活動量の少ない人々に比べて, 摂取すべきエネルギー量 が増加し, 各種栄養素の摂取量も増やす必要がある。そ の中でも水溶性ビタミンは, 体内保留量が少ないため, 日々の摂取に配慮が必要である。特にビタミン $\mathrm{B}_{1}, \mathrm{~B}_{2}$ (以下, $\mathrm{VB}_{1}, \mathrm{VB}_{2}$ ) について, van der Beekら ${ }^{1 \sim 3)}$ は, 摂取量を RDAの $1 / 3$ 程度 $(0.42 \mathrm{mg} /$ 日）まで制限すると， 血中乳酸の増加及び $10 \sim 15 \%$ の最大酸素摂取量の低下 がみられ，パフォーマンスに悪影響を与えることを報告 している。しかし, スポーツ選手の栄養状態に関する報 告によれば, $\mathrm{VB}_{1}$ の栄養状態が潜在性欠乏状態である選 手の存在が認められている ${ }^{4 \sim 8)}$ 。また, ビタミンC （VC）はストレス関連ホルモンの代謝に関与しており,
精神的, 身体的ストレスが加わることにより必要量が増 加するといわれている ${ }^{9)}$ 。更に, VCは非へム鉄の吸収 促進 ${ }^{10)}$ やコラーゲンの合成にも関与しており, 最近で

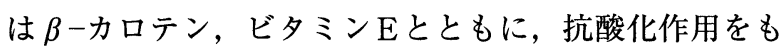
つビタミン ${ }^{11)}$ としても注目されている。

しかし，スポーツ選手の適正なビタミン摂取量につい ては, 血中濃度や補酵素添加効果などの生化学的指標を 評価尺度として, 良好な状態に維持, あるいは改善する ために必要な㩒取量を明確に示した報告は少なく，現在 のところ定められていない ${ }^{12)}$ 。そこで本研究では, 大学 女子テニス選手の水溶性ビタミンの攝取状況調査とビ夕 ミンの栄養状態の評価を一般女子学生との比較で検討し た。

\footnotetext{
Key words : collegiate female tennis player, vitamin $\mathrm{B}_{1}$, vitamin $\mathrm{B}_{2}$, vitamin $\mathrm{C}$
} 大学女子テニス選手, ビタミン $\mathrm{B}_{1}$, ビタミン $\mathrm{B}_{2}$, ビタミンC

（連絡先：桶口 満 † 162-8636 東京都新宿区戸山1-23-1 電話 03-3203-5603 FAX 03-3204-1761 E-mail mhiguchi@nih.go.jp) 
方

法

\section{1. 対象者}

関東大学テニスリーグ 1 部 A大学テニス部に所属する 女子 17 人及び, 特に運動を行っていない一般女子大学 生13人を対象とした。本研究にあたっては, ヘルシン キ宣言の精神を遵守し, 対象者に実験方法を説明し, 全 員の同意を得た。

\section{2. 身体計測}

各対象者に対して，身体計測（身長，体重，皮脂厚） を行った。皮脂厚は栄研式皮厚計にて上腕背部と肩甲骨 下部を測定し，体脂肪率は長嶺らの方法により身体密度 を算出し，それをBrozekの式に当てはめて推計した ${ }^{13) 。}$

\section{3. 栄養摂取状況調查}

大学女子テニス選手は夏季のトレーニング期（1998 年 8 月または 1999 年 8 月）において，一般女子大学生 は同時期の平常日において，採血日の直前 3 日間の食物 摄取状況調查を行った。調查方法は，各個人に調查用紙 及び秤を渡し，原則として秤量法で行った。秤量不可能 なものについては目安量を，また薬凨及びビタミン夙等 の栄養補助剂や栄養強化食品を摂取しているものについ ては，それらも記載するようにした。調査用紙回収時に は，管理栄養士が聞き取りを行い，献立・食材とその摂 取量を確認した。調查用紙を基に，「四訂日本標準食品 成分表」 ${ }^{14)}$ から各栄養素摂取量を算出した。なお，調 理によるビタミンの損耗については考慮しなかった。

更に大学女子テニス選手については，食事調查期間と 同時期に生活時間調查を行い，「第六次改定日本人の栄 養所要量一食事摂取基準一」12) を参考に，「日常生活の 動作強度の目安」を用いてエネルギー消費量を算出した。

\section{4.ビタミンの栄養状態}

(1) 採血及び検体前処理

食物摂取状況調查終了の翌日，早朝空腹時に肘静脈よ

り $5 \mathrm{ml}$ のヘパリン加採血を行った。

血液は，遠心分離により血漿と赤血球に分け，血漿は $0.5 \mathrm{~m} l$ を $30 \%$ メリリン酸 $0.5 \mathrm{~m} l$ と混合したものを $\mathrm{VC}$ 測定 用の試料とし，上清及びバッフィーコートを除去し，分 離した赤血球を生理食塩水にて 3 回洗浄し，赤血球と同 量の純水を混合した溶赤血球を $\mathrm{VB}_{1}$ 及び $\mathrm{VB}_{2}$ 測定用の試 料とした。これらは直ちに $-80^{\circ} \mathrm{C} て ゙$ 凍結し，測定まで 保存した。

（2）ビタミンの栄養状態の評価

$\mathrm{VB}_{1}$ の栄養状態の評価は, Takeuchi ら ${ }^{15)}$ の溶血球中 トランスケトラーゼ活性の TDP 添加効果法により測定 した。この方法はHenkら ${ }^{16)}$ によって推奨されている方 法で，TDPはトランスケトラーゼの補酵素であり， $\mathrm{VB}_{1}$ が不足するとトランスケトラーゼ活性が低下することか ら, TDP 添加前後のトランスケトラーゼ活性の変化を
表 1 対象者の身体的特徴

\begin{tabular}{llcc}
\hline & & $\begin{array}{c}\text { テニス選手 } \\
(n=17)\end{array}$ & $\begin{array}{c}\text { 一般学生 } \\
(n=13)\end{array}$ \\
\hline 年歯 & $($ 歳 $)$ & $20 \pm 1$ & $20 \pm 1$ \\
身長 & $(\mathrm{cm})$ & $163.4 \pm 3.8^{*}$ & $158.6 \pm 4.4$ \\
体重 & $(\mathrm{kg})$ & $56.8 \pm 6.3^{*}$ & $51.0 \pm 3.4$ \\
$\mathrm{BMI}$ & $\left(\mathrm{kg} / \mathrm{m}^{2}\right)$ & $21.2 \pm 1.9$ & $20.3 \pm 1.2$ \\
体脂肪率 & $(\%)$ & $19.1 \pm 4.3$ & $20.4 \pm 2.8$ \\
\hline${ }^{*} p<0.01$ & $(\mathrm{vs}$ 一般学生 $)$ & & $(\mathrm{M} \pm \mathrm{SD})$
\end{tabular}

みて, $\mathrm{VB}_{1}$ の栄養状態を評価するものである。本研究で は, $\mathrm{VB}_{1}$ についての基準は，橋詰ら ${ }^{177}$ ，横峯ら ${ }^{18)}$ の值を参

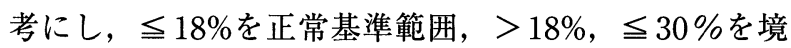
界域，>30\%を潜在性欠乏域として評価した。 $\mathrm{VB}_{2}$ の 栄養状態は, 溶血球中グルタチオン還元酵素活性の FAD 添加効果法 ${ }^{19 \sim 21)}$ により測定し, 結果判定の正常基 準範囲はミ1.3であり，>1.3を潜在性欠乏域として評価 した ${ }^{21}$ 。VCの栄養状態は，ヒドラジン法（DNP法； dinitrophenylhydrazine 法 ${ }^{22)}$ にて血漿 VC濃度を測定し, 橋詰の基準值を参考にし， $\geqq 0.7 \mathrm{mg} / \mathrm{d} l$ を正常基準範囲 とし，それ以下を潜在性欠そ域として評価した。

\section{5. 統計処理}

各群間における有意差検定は，一元配置分散分析を行 った。有意な分散がみられたものに関しては多重比較検 定を行った。二変量間の相関関係は回帰分析を用い，全 ての検定は $p<0.05$ もって有意とした。

\section{結果}

\section{1. 身体的特徵}

大学女子テニス選手及び一般女子大学生の身体的特徴 について，表 1 に示した。テニス選手は，一般学生に対 して，身長，体重ともに有意に大きく，体脂肪率は低い 傾向（ $p=0.054 ） に$ にった。

2. エネルギー摂取量及び各種栄養素, 食品群別摄取 状況

エネルギー及び栄養素摂取量を表 2 に示した。食物摄 取状況調査の結果，大学女子テニス選手にビタミン郕摂 取者が 2 人, ビ夕ミン剂及びプロテイン摂取者が 1 人, アミノ酸摂取者が 1 人（以下，サプリメントとする）存 在した。この 4 選手は，テニス選手サプリメント非摂取 者と分けて検討した。一般学生の中には, サプリメント を摂取していた者はいなかった。

テニス選手サプリメント摂取者は，非摂取者に比べ, たんぱく質， $\mathrm{VB}_{1}, \mathrm{VB}_{2}$ 摂取量が有意に多かった。また， 一般学生に比べ，エネルギー，たんぱく質，糖質， $\mathrm{VB}_{1}$, $\mathrm{VB}_{2}$ ，VCの㠌取量が有意に多く，たんぱく質エネルギ 一比が有意に高かった。テニス選手サプリメント摄取者 
表 2 エネルギー及び栄養素摂取状況

\begin{tabular}{|c|c|c|c|c|}
\hline & & \multicolumn{2}{|c|}{ テニス選手 } & \multirow{2}{*}{$\begin{array}{l}\text { 一般学生 } \\
(n=13)\end{array}$} \\
\hline & & $\begin{array}{c}\text { サプリメント摂取者 } \\
(n=4)\end{array}$ & $\begin{array}{c}\text { サプリメント非摂取者 } \\
(n=13)\end{array}$ & \\
\hline エネルギー & (kcal) & $2,394 \pm 253^{\# \#}$ & $1,936 \pm 375$ & $1,692 \pm 339$ \\
\hline \multirow[t]{2}{*}{ たんぱく質 } & $(\mathrm{g})$ & $87.7 \pm 16.5^{\text {**\#\# }}$ & $57.2 \pm 15.2$ & $58.8 \pm 14.0$ \\
\hline & （g/体重 kg） & $1.65 \pm 0.47^{* * \#}$ & $1.00 \pm 0.23$ & $1.20 \pm 0.30$ \\
\hline 脂質 & (g) & $73.3 \pm 10.2$ & $61.1 \pm 17.8$ & $62.8 \pm 20.1$ \\
\hline 糖質 & $(\mathrm{g})$ & $355.8 \pm 48.9^{\# \#}$ & $292.1 \pm 97.1^{\#}$ & $213.6 \pm 38.5$ \\
\hline \multicolumn{5}{|c|}{ エネルギー比率 } \\
\hline $\mathrm{P}$ & $(\%)$ & $14.7 \pm 3.0^{*}$ & $11.7 \pm 1.2^{\#}$ & $13.9 \pm 2.1$ \\
\hline $\mathrm{F}$ & $(\%)$ & $27.6 \pm 3.6$ & $28.3 \pm 5.9$ & $32.9 \pm 5.3$ \\
\hline $\mathrm{C}$ & $(\%)$ & $57.6 \pm 2.0$ & $59.9 \pm 5.8^{\#}$ & $53.2 \pm 6.1$ \\
\hline \multirow[t]{2}{*}{ ビタミン $B_{1}$} & $(\mathrm{mg})$ & $9.35 \pm 12.26^{* * \# \#}$ & $0.92 \pm 0.24$ & $0.83 \pm 0.27$ \\
\hline & (mg/1,000kcal) & $3.98 \pm 5.37^{* * \# \#}$ & $0.48 \pm 0.10$ & $0.49 \pm 0.10$ \\
\hline \multirow[t]{2}{*}{ ビタミン $\mathrm{B}_{2}$} & $(\mathrm{mg})$ & $9.26 \pm 12.34^{* * \# \#}$ & $1.29 \pm 0.53$ & $1.06 \pm 0.38$ \\
\hline & $(\mathrm{mg} / 1,000 \mathrm{kcal})$ & $3.97 \pm 5.40^{* \#}$ & $0.65 \pm 0.20$ & $0.63 \pm 0.19$ \\
\hline ビタミンC & $(\mathrm{mg})$ & $506 \pm 389^{\#}$ & $315 \pm 263^{\#}$ & $91 \pm 46$ \\
\hline
\end{tabular}

のサプリメント由来のエネルギーは, $49.6 \pm 40.2 \mathrm{kcal}$, たんぱく質 $7.0 \pm 9.2 \mathrm{~g}$ ，脂質 $1.1 \pm 1.0 \mathrm{~g}$ ，糖質 $3.8 \pm 3.9 \mathrm{~g}$ であった。テニス選手サプリメント非摂取者は, 一般学 生に比べ，糖質，VC摂取量が有意に多く，たんぱく質 エネルギー比が有意に低く, 糖質エネルギー比率が有意 に高かった。エネルギー消費量は, テニス選手サプリメ ント攝取者が $2,138 \pm 290 \mathrm{kcal}$, 非摂取者が $2,103 \pm$ $348 \mathrm{kcal}$ で, サプリメント摂取者, 非摂取者ともエネル ギー摂取量との有意な差はみられなかった。

$\mathrm{VB}_{1}, \mathrm{VB}_{2}$ 摂取量とエネルギー摂取量との関係をテニ ス選手サプリメント非摂取者と一般学生を併せて検討し たところ, $\mathrm{VB}_{1}, \mathrm{VB}_{2}$ 摂取量とエネルギー摄取量には有意

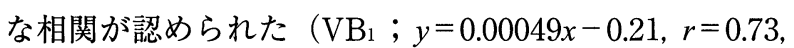
$\left.p<0.01, \mathrm{VB}_{2} ; y=0.00088 x-0.41, r=0.70, p<0.001\right)$ 。大 学女子テニス選手及び一般女子大学生の水溶性ビタミン 摂取量を「第六次改定日本人の栄養所要量一食事摂取基 準一」 ${ }^{12)}$ に従って，VB1 $\mathrm{VB}_{1}$ エネルギー摂取量 $1,000 \mathrm{kcal}$ 当たり $0.42 \mathrm{mg}, \mathrm{VB}_{2}$ はエネルギー摂取量 $1,000 \mathrm{kcal}$ 当た り $0.48 \mathrm{mg}, \mathrm{VC} は 100 \mathrm{mg}$ を基準量とし, 個々人の攝取 量を検討した。その結果， $\mathrm{VB}_{1}$ の基準量を満たしていな い者がテニス選手サプリメント非摂取者に 4 人，一般学 生に 3 人, $\mathrm{VB}_{2}$ の基準量を満たしていない者がテニス選 手サプリメント非摂取者に 1 人, 一般学生に 3 人, VC の基準量を満たしていない者がテニス選手サプリメント 非摂取者に 3 人，一般学生に 8 人存在した。

対象者の食品群別摂取量を表 3 に示した。テニス選手
表3 食品群別摂取状況

\begin{tabular}{|c|c|c|c|}
\hline \multirow[b]{2}{*}{ 食品群 } & \multicolumn{2}{|c|}{ テニス選手 } & \multirow[b]{2}{*}{$\begin{array}{l}\text { 一般学生 } \\
(n=13)\end{array}$} \\
\hline & $\begin{array}{c}\text { サプリメント } \\
\text { 摂取者 } \\
(n=4)\end{array}$ & $\begin{array}{c}\text { サプリメント } \\
\text { 非攝取者 } \\
(n=13)\end{array}$ & \\
\hline 穀類 & $338 \pm 54^{* \#}$ & $240 \pm 70$ & $233 \pm 81$ \\
\hline いも類 & $14 \pm 9$ & $26 \pm 32$ & $31 \pm 24$ \\
\hline 砂糖類 & $4 \pm 4$ & $5 \pm 7$ & $4 \pm 3$ \\
\hline 油脂類 & $9 \pm 4$ & $8 \pm 6^{\#}$ & $27 \pm 33$ \\
\hline 豆類 & $104 \pm 53^{* * \# \#}$ & $12 \pm 15$ & $15 \pm 5.2$ \\
\hline 魚介類 & $34 \pm 18^{* *}$ & $10 \pm 12^{\#}$ & $38 \pm 36$ \\
\hline 獣鷄鯨肉類 & $107 \pm 37$ & $85 \pm 56$ & $76 \pm 58$ \\
\hline 卵類 & $14 \pm 23$ & $31 \pm 24$ & $42 \pm 44$ \\
\hline 乳類 & $314 \pm 199^{\#}$ & $233 \pm 175$ & $144 \pm 111$ \\
\hline \multicolumn{4}{|l|}{ 野菜類 } \\
\hline 緑黄色野菜 & $35 \pm 1$ & $32 \pm 31$ & $86 \pm 93$ \\
\hline その他の野菜 & $139 \pm 108^{*}$ & $60 \pm 36^{\#}$ & $114 \pm 64$ \\
\hline 果実類 & $232 \pm 77^{\#}$ & $187 \pm 122^{\#}$ & $73 \pm 100$ \\
\hline きのこ類 & $8 \pm 10^{*}$ & $1 \pm 3$ & $3 \pm 5$ \\
\hline 海藻類 & $2 \pm 3$ & $4 \pm 4$ & $5 \pm 15$ \\
\hline 菓子類 & $83 \pm 76^{\#}$ & $65 \pm 69$ & $27 \pm 33$ \\
\hline 嗜好飲料 & $532 \pm 399^{\#}$ & $754 \pm 460^{\# \#}$ & $161 \pm 244$ \\
\hline
\end{tabular}

${ }^{*} p<0.05,{ }^{* *} p<0.01$ (vs テニス選手サプリメント非摂 取者), \#p<0.05, \# $p<0.01$ (vs 一般学生)

$(\mathrm{M} \pm \mathrm{SD} ; \mathrm{g})$

サプリメント摂取者は, 非摂取者に比べ, 穀類, 豆類, 魚介類, その他の野菜類, きのこ類の摂取量が有意に多 


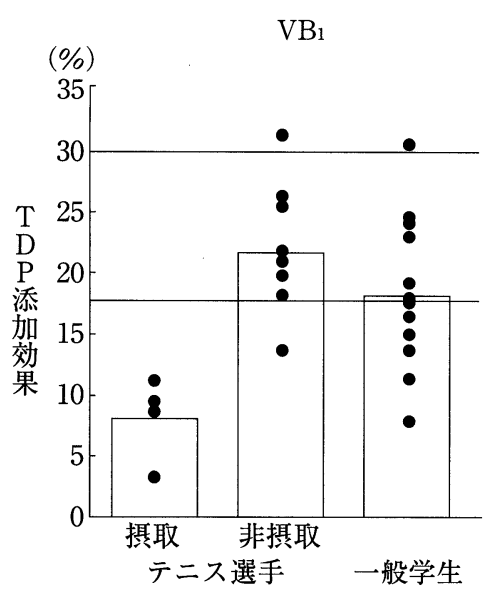

$\mathrm{VB}_{2}$

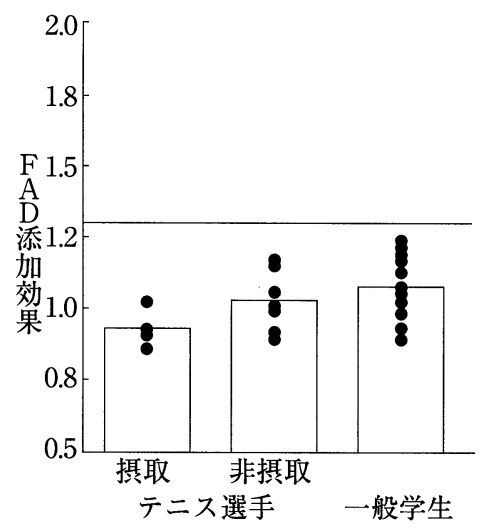

図 1 ビタミンの栄養状態
$\mathrm{VC}$

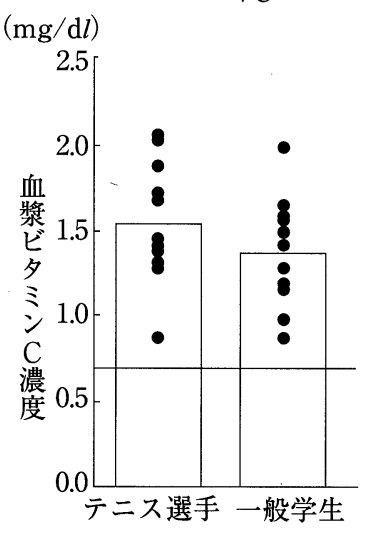

平均值

個人

テニス選手サプリメント摂取 $(n=4)$, 非摂取量 $(n=13)$, 一般学生 $(n=13)$

TDP 添加効果 : 基準範囲 ; $\leqq 18 \%$ ，境界域 ; $>18 \% ， \leqq 30 \%$ ，潜在性欠乏域 ; $>30 \%$

$\mathrm{FAD}$ 添加効果 : 基準範囲 $; \leqq 1.3$, 潜在性欠乏域 $;>1.3$

血漿 $\mathrm{VC}$ 濃度 : 基準範囲 $; \geqq 0.7 \mathrm{mg} / \mathrm{d} l$, 潜在性欠乏域 $;<0.7 \mathrm{mg} / \mathrm{d} l$

かった。また, 一般学生に比べ, 款類, 豆類, 果実類, 菓子類, 嗜好飲料の摄取量が有意に多かった。テニス選 手サプリメント非摂取者は, 一般学生に比べ, 油脂類, 魚介類, その他の野菜類の摂取量が有意に少なく, 果実 類，嗜好飲料の摄取量が有意に多かった。

\section{3. ビタミンの栄養状態}

テニス選手と一般学生のビタミンの栄養状態を図 1 に 示した。TDP添加効果の平均值は, テニス選手サプリ メント非掑取者で境界域の值を示し, 正常基準範囲 2 人, 境界域 10 人，潜在性欠乏域 1 人であった。サプリメン 卜掑取者の TDP 添加効果は, 正常基準範囲の值を示し, 非摂取者に比べて有意に低い值であった。一般学生の TDP 添加効果の平均值も境界域の値を示し, 正常基準 範囲 7 人, 境界域 5 人, 潜在性欠乏域 1 人であった。 FAD 添加効果は, 全てのテニス選手及び一般学生とも に正常基準範囲内であった。血漿中 $\mathrm{VC}$ 濃度は, 全ての テニス選手及び一般学生ともに正常基準範囲内であっ た。

4. ビタミン摂取状況とビタミンの栄養状態との関係 栄養状態が悪かった $\mathrm{VB}_{1}$ の摂取状況と TDP 添加効果 の関係について，更に検討を行った。テニス選手サプリ メント非摂取者, 一般学生の摂取量 $(\mathrm{mg} /$ 日) と TDP 添加効果の間には, 統計的に有意な相関がみられなかっ た。テニス選手サプリメント非掑取者についてみると， エネルギー摄取量 $1,000 \mathrm{kcal}$ 当たりの摄取量 (mg/1,000kcal) と TDP 添加効果との間には, 有意な負 の相関が忍められた（図 2 )。しかし，一般学生のエネ ルギー摂取量 $1,000 \mathrm{kcal}$ 当たりの摂取量 (mg/1,000kcal) と TDP 添加効果との間には有意な相関は認められなか

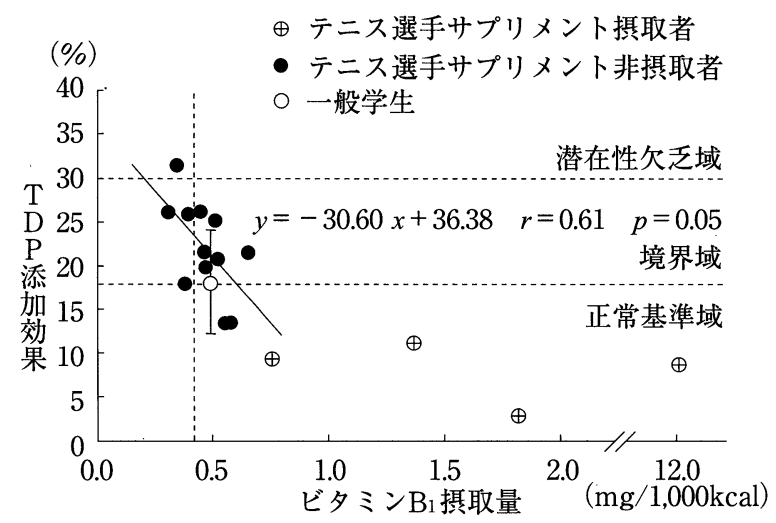

図 2 ビタミン $\mathrm{B}_{1}$ 撖取量とTDP添加効果の関係

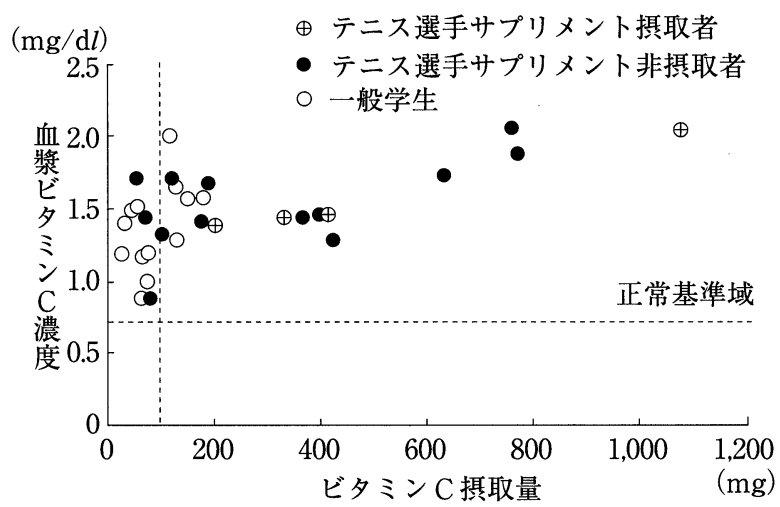

図 3 ビタミンC摂取量と血中濃度の関係

った。図 2 に示したテニス選手サプリメント非摂取者に 対する回帰直線から TDP 添加効果が正常基準範囲の上 限值（18\%）に相当する摄取量を求めると， $0.60 \mathrm{mg}$ で あった。

VCの栄養状態を個別に検討するために, 摂取量と血 
漿 $\mathrm{VC}$ 濃度の関係を図 3 に示した。血漿 $\mathrm{VC}$ 濃度は摂取 量の増加に伴い増加傾向を示しているが, $800 \mathrm{mg}$ 以上 の摂取では $2.0 \mathrm{mg} / \mathrm{d} l$ でほぼ横ばい，200〜 $400 \mathrm{mg}$ の摄 取では $1.5 \mathrm{mg} / \mathrm{d} l$ 程度であった。

\section{考察}

平成 10 年国民栄養調查 ${ }^{23)}$ によると, 20 歳代女性の平

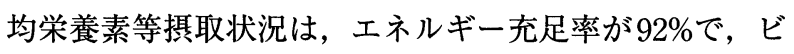
タミンについては充足していると報告されている。しか し, 古典的なビタミン欠乏症は減少したものの,「豊か な食生活」を背景に生化学的診断によって初めて明らか になる潜在性ビタミン久そ状態は依然として存在すると いわれている ${ }^{24)}$ 。このような食生活状況におかれている ことは，スポーツ選手も例外ではない。

表 2 に示したとおり，テニス選手サプリメント摂取者 のエネルギー摂取量は一般学生と比べると有意に多かっ たが, 非摂取者と一般学生の間には差はみられなかった。 テニス選手の調査時期である夏季は, インカレ（大学選 手権）が開催されるほか，多くのオープン大会が開催さ れている。本研究の対象となったテニス選手は各自のレ ベルに合わせた大会に出場しており，選手それぞれのト レーニング状況はオンコートでの技術練習が主であっ た。

オンコートでの技術練習についての細かいエネルギー 消費量は測定されていないので，「第六次改定日本人の 栄養所要量一食事摂取基準一」12) を参考に，「日常生活 の動作強度の目安」を用い，テニス選手のエネルギー消 費量を概算したところ，攖取量との有意な差はみられな かった。調査日は試合日を避けて設定したものの, 調整 程度のトレーニング量であった選手もいたため, 消費エ ネルギーが少なかったものと考えられる。一般学生につ いては, 日常的に運動・スポーツを行っていないことを 確認しており, 生活活動強度は「第六次改定日本人の栄 養所要量一食事摄取基準一」12) でいう III(やや低い)に 相当するものと考えられる。

$\mathrm{VB}_{1}$ の栄養状態について, 本研究では TDP 添加効果 を用い判定を行った。 $\mathrm{VB}_{1}$ の最少必要量を摄取していた 対象者にはTDP 添加効果が $18 \%$ 以上を示す者がいなか ったという橋詰ら ${ }^{17)}$ の結果，また，正常健康人の $90 \%$ がTDP添加効果 0〜30\%であったという横峯ら ${ }^{18)}$ の結 果を基に基準値を設定した。この基準值は，スポーツ愛 好者, 選手に対しても使われている ${ }^{5 \sim 8,25,26)}$ 。

本研究では, $\mathrm{VB}_{1}$ の栄養状態が境界域・潜在性欠乏域 に含まれる対象者が多かった。この理由として，VB⿺ 豊富に含む食品が豚肉や豚肉製品，うなぎなどに限られ ること, また本研究の対象者は外食, コンビニ食が多く, 自炊者においても食材が偏り, $\mathrm{VB}_{1}$ の供給源となり得る
いも類，大豆製品，野菜類，魚介類などの掑取量が少な かったことが考えられる。テニス選手と一般学生では, 油脂類と魚介類, その他の野菜, 果実類, 嗜好飲料の摂 取量に統計的に有意な差がみられた。しかし，油脂類は $\mathrm{VB}_{1}, \mathrm{VB}_{2}$ をほとんど含んでおらず，その他の野菜，果 実類からも $\mathrm{VB}_{1}, \mathrm{VB}_{2}$ の摂取はあまり期待できない。魚 介類からは $\mathrm{VB}_{1}, \mathrm{VB}_{2}$ の摂取が期待できるが，それぞれ の摂取量が少なかったため, 両グループ間の $\mathrm{VB}_{1}, \mathrm{VB}_{2}$ 掑取量や栄養状態に影響が出なかったものと思われた。

今までに報告された $\mathrm{VB}_{1}$ 摂取量と栄養状態の研究によ れば, 食事提供実験では有意な相関がみられるものの ${ }^{27)}$, 食事調查結果では有意な相関がみられないとの報告が多 く28,29), 我々の先行研究でも, TDP 添加効果で判定した 場合には総 $\mathrm{VB}$ 撕取量との関係が明確ではなかった 6,26。 本研究においても，テニス選手サプリメント非摂取者, 一般学生のどちらにおいても, 総 $\mathrm{VB}_{1}$ 摂取量と TDP 添 加効果の間には有意な相関がみられなかった。

しかし，糖代謝はエネルギーを得るための重要な経路 であり, $\mathrm{VB}_{1}$ は糖代謝経路の補䣲素として働くことから， $\mathrm{VB}_{1}$ 要求量はエネルギー代謝と関連させて考えられてお り，単位エネルギー量当たりの摃取基準量が設定されて いる ${ }^{12,30)}$ 。従って, 血中 $V_{B}{ }_{1}$ の栄養状態についても， 1 日当たりの撖取量よりも単位エネルギー量当たりの摄取 量に影響される可能性が高いことが考えられる。「第六 次改定日本人の栄養所要量一食事摄取基準一」12) では $0.42 \mathrm{mg} / 1,000 \mathrm{kcal}$ という基準量が設定されているが, 本 研究では，運動の有無にかかわらず，境界域・潜在性欠 忌域に含まれる者が存在した。特に，テニス選手サプリ メント非摂取者に扔いて，VB撖取量 $(\mathrm{mg} / 1,000 \mathrm{kcal})$ と TDP 添加効果值には有意な負の相関がみられた（図 2 )。この結果は, $\mathrm{VB}_{1}$ 摂取量を単位エネルギー量当た りで設定することを支持するものと考えられる。しかし， 一般学生においては同様の結果は得られていないので, $\mathrm{VB}_{1}$ の栄養状態の変化は, 運動習慣のある人において顕 著になると思われた。更に, 一般学生には, 基準㠌取量 を下回っていても TDP 添加効果が正常基準域に入る者 が 2 人みられた。しかし，その理由として述べられるよ うな特徴的な食事・栄養素摂取状況はみられなかった。 個人の $\mathrm{VB}_{1}$ 吸収能力や，利用効率が異なった可能性が考 えられるが，今回の結果からは明らかではない。

図 2 に示したテニス選手サプリメント非摂取者の回帰 直線から TDP 添加効果の值が境界域（18\%）以下にな る $\mathrm{VB}_{1}$ 摂取量を求めると， $0.60 \mathrm{mg} / 1,000 \mathrm{kcal}$ であった。 計算上は，その量以上を摂取すれば栄養状態を改善でき る可能性がある。しかし, 本研究の対象となったテニス 選手のエネルギー消費量は $2,100 \mathrm{kcal}$ 前後であり, $\mathrm{VB}_{1}$ を $0.60 \mathrm{mg} / 1,000 \mathrm{kcal}$ 以上摂取していても TDP 添加効果 
が $18 \%$ 上回る選手も存在したことから, 著しい消費エ ネルギー量の増加が $\mathrm{VB}_{1}$ 必要量に与える影響について は，更に検討が必要である。

$\mathrm{VB}_{2}$ に関しては, 一般女子大学生, サプリメントを摂 取していないテニス選手ともに平均摄取量は「第六次改 定日本人の栄養所要量一食事撖取基準一」12) の基準量を 上回っており，栄養状態に関しては潜在性欠乏状態であ る者はいなかった。 $\mathrm{VB}_{2}$ は, 肉類, 卵類, 牛乳・乳製品 など, 比較的多種類の食品に含まれているため摂取しや すいことが考えられる。本調查結果でも, 摂取エネルギ 一量の増加に伴って $\mathrm{VB}_{2}$ の摂取量は増加しており, 基準 量をほぼ満たしていた。従って, $\mathrm{VB}_{2}$ は, 一般学生, テ ニス選手ともに「第六次改定日本人の栄養所要量一食事 摂取基準一」12)に従い，基準量の摂取を心がけることに よって, 血中 $\mathrm{VB}_{2}$ の栄盖状態が良好に保たれるものと考 えられる。

VCに関しては，一般学生の平均摂取量は基準量より も若干少なかったが, 血漿 $\mathrm{VC}$ 濃度が潜在性欠乏状態に 含まれる者はいなかった。テニス選手では, $\mathrm{VC}$ 平均摂 取量は基準量よりも多く摃取されており, 血漿 $\mathrm{VC}$ 濃度 が潜在性欠乏状態である者はいなかった。これは VC 摂 取状況（表 4 ）に示すとおり, 調査時期が夏季であった ため, スポーツドリンク，抒茶, 果汁 $100 \%$ ジュースな ど市販嗜好飲料の摂取量が多くなり，それらの飲料に含 まれていた VCを損取したために血漿 $\mathrm{VC}$ 濃度が高くな ったものと思われる。飲料及びサプリメント以外から， 「第六次改定日本人の栄養所要量一食事摂取基準一」12) の基準量である $100 \mathrm{mg}$ 以上の VCを摂取していたテニス 選手は 2 人であった。夏季のように水分摂取のために市 販嗜好飲料を多飲するような状況下では, VCの栄養状 態は良好に保たれるが, 冬季のように飲料の摄取量が少 なくなることが予想される時期では, 野菜類や果物類の 撖取が少ないと, VCの栄養状態が悪くなる可能性が懸 念される。

一方，一般学生では摂取した VCのほとんどが飲料以

表 4 ビタミンC 摂取状況

\begin{tabular}{|c|c|c|c|}
\hline \multirow[b]{2}{*}{ 供給源 } & \multicolumn{2}{|c|}{ テニス選手 } & \multirow[b]{2}{*}{$\begin{array}{l}\text { 一般学生 } \\
(n=13)\end{array}$} \\
\hline & $\begin{array}{l}\text { サプリメント } \\
\text { 掑取者 } \\
(n=4)\end{array}$ & $\begin{array}{c}\text { サプリメント } \\
\text { 非撖取者 } \\
\quad(n=13)\end{array}$ & \\
\hline 食品 & $76 \pm 41$ & $38 \pm 29$ & $74 \pm 47$ \\
\hline 飲料 & $278 \pm 305$ & $277 \pm 268^{\#}$ & $16 \pm 31$ \\
\hline サプリメント & $153 \pm 136$ & - & - \\
\hline 合計 & $506 \pm 389^{\#}$ & $315 \pm 263^{\#}$ & $91 \pm 46$ \\
\hline
\end{tabular}

\# $p<0.05$ (vs 一般学生)

$(\mathrm{M} \pm \mathrm{SD} ; \mathrm{mg})$
外の食品由来のものであり, 平均 $\mathrm{VC}$ 摂取量は基準量の 100mg よりやや少なかったが, 血漿 VC濃度をみると潜 在性欠乏状態に含まれる者はいなかった。なお，テニス 選手と一般学生の平均 $\mathrm{VC}$ 摂取量には 3 倍以上の差があ ったにもかかわらず，血漿 $\mathrm{VC}$ 濃度には有意な差がみら れなかった。

Levine ら ${ }^{311}$ は, 成人男性において, 血槳 $\mathrm{VC}$ 濃度はVC 投与量が 1 日 $1,000 \mathrm{mg}$ で完全なプラトー值 $(1.4 \mathrm{mg} / \mathrm{d} l)$ になり， $60 \mathrm{mg}$ ではプラトー值の $1 / 3,100 \mathrm{mg}$ でプラト 一值の $2 / 3,200 \mathrm{mg}$ でプラトー值に近づくと報告してい る。また, Rokitzkiら ${ }^{32)}$ は，摂取量がほぼ同じである 場合，アスリートと非鍛錬者の間にも，アスリートの競 技種目間にも，有意な差は認められないことを報告して いる。そしてこの理由として, 摂取量が多く（平均； $181 \mathrm{mg}$, 範囲 ; 188〜 239mg), 血漿 VC 濃度がプラトー に近づいていたためとしている（平均； $1.24 \mathrm{mg} / \mathrm{d} l$, 範 囲；1.16 $1.41 \mathrm{mg} / \mathrm{d} l)$ 。本研究に打いてもほほ同様な 傾向が認められ, VCは $200 \mathrm{mg}$ 程度の摂取で血漿 $\mathrm{VC}$ 濃 度はほぼ横ばいを示した。

以上のことょり， $\mathrm{VB}_{1}$ に関しては，潜在性欠そ状態に 陥りやすいため, $\mathrm{VB}_{1}$ の供給が期待できる食品群の摂取 量を増やし,「第六次改定日本人の栄養所要量一食事摂 取基準一」12)に設定されている以上の撕取を心がける必 要があることが示唆された。

\section{要 約}

本研究では, 大学女子テニス選手及び一般学生を対象 に, 水溶性ビタミン $\left(\mathrm{VB}_{1}, \mathrm{VB}_{2}, \mathrm{VC}\right)$ の摄取状況調査 と栄養状態の評価を行った。テニス選手サプリメント摂 取者は, 非撕取者, 一般学生よりも有意に多くエネルギ 一を摂取していた。サプリメントを摂取していないテニ 又選手，一般学生ともに，VB1 栄養所要量一食事摂取基準一」の基準量以上摂取してい たが，TDP（チアミン 2 リン酸）添加効果は境界域の 值を示した。テニス選手サプリメント非摂取者の摂取量 (mg/1,000kcal) と TDP 添加効果の間には, 有意な負の 相関がみられた。得られた回帰直線から, TDP 添加効 果が正常基準範囲の上限值（18\%）に相当する損取量を 求めると $0.60 \mathrm{mg}$ であった。テニス選手サプリメント非 摄取者, 一般学生ともに, $\mathrm{VB}_{2}$ を「第六次改定日本人の 栄養所要量一食事摂取基準一」の基準量以上摄取してお り, FAD（フラビンアデニン 2 ヌクレオチド）添加効 果は正常基準範囲の值を示した。また，テニス選手サプ リメント摄取者は, $\mathrm{VB}_{1}, \mathrm{VB}_{2}$ ともに基準量を大きく上 回った摂取量で, それらの栄養状態も良好であった。 $\mathrm{VC}$ の掑取量は, テニス選手サプリメント掑取者, 非攝 取者とも「第六次改定日本人の栄養所要量一食事摂取基 
準一」の基準量以上であったが，一般学生は基準量をや や下回っていた。全対象者ともに血漿 VC濃度は基準範 囲であった。

本研究にご協力頂いた選手の皆様, 並びに亜細亜大学 堀内昌一先生に深く感謝致します。本研究は, (財)日本 体育協会スポーツ科学専門委員会の委託費を受け, 平成 10 年度, 平成 11 年度「スポーツ選手に対する最新の栄 盖・食事ガイドライン策定に関する研究」の一環として 行われた。

なお, 本研究の大要は, 第 54 回日本体力医学会（平 成 11 年 9 月, 熊本), 第 11 回テニス学会（平成 11 年 11 月，東京）において発表した。

\section{文献}

1) Beek van del, E.J., Dokkum van, W., Schrijver, J.A., Weerd van de, H. and Hermus, R.J.J. : Effect of marginal vitamin intake on physical performance of man, Int. J. Sports Med., 5, 28 31 (1984)

2) Beek van del, E.J., Dokkum van, W., Schrijver, J.A., Wedel, M., Gaillarad, A.W.K., Wesstra, A., Weed van de, H., and Hermus, R.J.J. : Thamin, riboflavin and vitamin $\mathrm{B}_{6}$ : inpact of combined restricted intake on functional performance of man, Am. J. Clin. Nutr., 48, 1451 1462 (1988)

3) Beek van del, E.J., Dokkum van, W., Schrijver, J.A. and Berg van den, H. : Thamin, riboflabin and vitamin $\mathrm{B}_{6}$ : inpact of restricted intake on physical performance of man, J. Am. Coll. Nutr., 13, 629 640 (1994)

4) Beek van del, E.J. : Vitamin supplementation and physical exercise performance, J. Sports Sci., 9, Special issue, $77 \sim 89$ (1991)

5）小林修平，山川喜久江，長嶺晋吉：IV 食物摄取状 況調查及び血液生化学検查から見たスポーツ選手のビタ ミン栄養状態の評価, 昭和 60 年度日本体育協会スポー ツ医・科学研究報告 No.IV スポーツ選手のビタミン要 求量に関する研究 (1986)

6）長谷川いずみ，井上喜久子，石井恵子，樋口 満：高校男子スケート選手の栄養状態一ビタミン $\mathrm{B}_{1}$ 及 び $\mathrm{B}_{2}$ について一, 栄養学雑誌, 53, 59〜66 (2000)

7）樋口 満：食事からのビタミン $\mathrm{B}_{1}$ 補給が大学水 泳選手の血中ビタミン $\mathrm{B}_{1}$ 栄養状態に与える影響, 平成 9 年度日本体育協会スポーツ医・科学研究報告 No.IX スポーツ選手に対する最新の栄養・食事ガイドライン策 定に関する研究 第 1 報 (1997)

8）杉浦克己：日本代表柔道選手の血中ビタミン栄養 状態および栄養摄取状況, 平成 11 年度日本体育協会又
ポーツ医・科学研究報告 No.IX スポーツ選手に対する 最新の栄養・食事ガイドライン策定に関する研究 第 3 報（2000）

9）飯島由美子, 添野尚子，猪俣美知子，塩入輝恵， 斎藤禮子, 木元幸一, 苫米地幸之助, 三田禮造, 井上喜 久子, 池上幸江, 小林修平：ストレス負荷によって起こ る身体的，精神的変化に及ぼす $\beta$ 一カロテン及びビタミ ンCの影響について, 栄養学雑誌, 53, 93〜102（1995）

10) Sean, R.L. : Interaction of iron with other nutrients, Nutrition Reviews, 55, 102 110 (1997)

11) Kanter, M.M., Nolte, L.A. and Holloszy, J.O. : Effect of an antioxidant vitamin mixture on lipid peroxidation at rest and postexercise, J. Appl. Physiol., 264, 965 969 (1993)

12）健康 - 栄養情報研究会編：第六次改定日本人の 栄盖所要量一食事摂取基準一（1999）第一出版, 東京

13）長嶺晋吉：皮下脂肪厚からの肥満の判定, 日本 医師会雑誌，68，919～924（1972）

14）第一出版編：四訂日本食品標準成分表（1993） 第一出版, 東京

15) Takeuchi, T., Nishino, K. and Itokawa, Y. : Improved determination of transketolase activity in erythrocytes, Clin. Chem., 30, 658 661 (1984)

16) Henk, V.D.B., Helmeut, H., Michel, L. and Brittmarie, S. : Flair concerted action No. 10 status papers introduction, conclusions and recommendations, Int. J. Vit. Nutr. Res., 30, $247 \sim 251$ (1993)

17）橋詰直孝, 上島待子 : 血中総ビタミン $\mathrm{B}_{1}$ 值, 溶 赤血球 Transketrase 活性值に対する検討とその臨床応 用，臨床病理，29，547～553（1981）

18）横峯凉子, 栗山 勝, 有馬寛雄, 井形昭弘：健 康人のビタミン $\mathrm{B}_{1}$ 代謝に関する生化学的検査一いわゆ る正常値に関して一，ビタミン，52，89～95（1978）

19) Glatzle, D., Korner, W.F., Christeller, S. and Wiss, O. : Method for the detection of a biochemical riboflavin deficiency. Stimulation of NADPH2-dependent glitathione reductase from human erythrocytes by $F A D$ in vitro. Investigations on the vitamin $\mathrm{B}_{2}$ status in healthy people and geriatric patients., Int. $Z$ Vitaminforsch, 40, 166 183 (1970)

20) Sauberlich, H.E., Dowdy, R.P. and Skala, J.H. : Laboratory test for the assessment of nutritional status., CRC Crit. Rev. Clin. Lab. Sci., 4, 215 340（1973）

21) Sauberlich, H.E., Judd, J.H., Nichoalds, G.E., Broquist, H.P. and Darby, W.J. : Application of the erythrocyte glutathione reductase assay in evaluating riboflavin nutrition status in a high school student pop- 
ulation, Am. J. Clin. Nutr., 25, 756 732 (1972)

22）日本ビタミン学会編：ビタミン学実験法 II

（1985）東京化学同人，東京

23）健康・栄盖情報研究会編：平成 10年国民栄養調 查結果の概要 $(2000)$

24）木村美恵子，狭山信矩，高島真知子，中林純子, 糸川嘉則, 恒松徳五郎：島根県無医村におけるビタミン B 1 栄養状態, 日衛誌, 36, 243 (1981)

25）木村典代，関根豊子，高橋裕子，井上喜久子, 岡 純, 书口 満: 中高年女性水泳愛好者の水溶性ビ夕 ミン $\left(\mathrm{B}_{1}, \mathrm{~B}_{2}, \mathrm{C}\right)$ の栄養状態, 栄養学雑誌, 59, 267 $\sim 271(2000)$

26）古旗照美, 井上喜久子, 石井恵子, 樋口 満 : 身体活動水準の異なる若年成人女性のビタミン栄養状 態, ビタミン, 72, 363〜 371（1998）

27) Saito, N., Kimura, M., Kuchiba, A. and Itokawa, Y. : The relationship between blood thiamine levels and dietry thiamine content in diabetic outpatients and healthy subjects, J. Nutr. Sci. Vitaminol., 33, 431 438 (1987)

28）安武 律, 城田知子, 西野幸典, 竹内 亨, 糸川 嘉則：九州地域における中年夫婦のビタミン $\mathrm{B}_{1}$ 摂取量 の現状とその評価について, 日本栄養・食糧学会誌, 45, 9 19 (1992)

29）平岡真実, 安田和人：女子大学生のビタミン $\mathrm{B}_{1}$, $\mathrm{B}_{2}$ 栄養状態に関する研究一全血総ビタミン $\mathrm{B}_{1}, \mathrm{~B}_{2}$ 濃度 分布範囲の検討一, ビタミン, 72, 679〜684（1998）

30) National Research Council : Recommended dietary allowance, 10th ed. (1989) National Academy Press, Washington, DC

31) Levine, M., Conry-Cantilena, C., Wang, Y., Welch, R.W., Washko, P.W., Dhariwal, K.R., Park, J.D., Lazarev, A., Graumlich, J.F., King, J. and Cantilena, L.R. : Vitamin $\mathrm{C}$ pharmacokinetics in healthy volunteers : Evidence for a recommended dietary allowance, Proc. Natl. Acad. Sci. USA, 93, 3704 3709 (1996)

32) Rokitzki, L., Hinkel, S., Klemp, C., Cifi, D. and Keul, J. : Dietary, serum and urine ascorbic acid status in male athletes, Int. J. Sports Med., 15, 435 440 (1994)

(受付: 平成 12 年 3 月 28 日) 